\title{
Wielokulturowe Inflanty Polskie. Część I
}

\author{
KRZYSZTOF ZAJAS
}

Kiedy w roku 2014 Rosja dokonała agresji na wschodnią Ukrainę, posługując się tzw. rebeliantami, czyli swoimi obywatelami zamieszkującymi najechane terytorium, wśród kolejnych zagrożonych regionów na poczesnym miejscu znalazła się łotewska Łatgalia. Leżąca na wschodzie Łotwy kraina stanowi bowiem dzisiaj obszar zamieszkały w przeważającej części przez ludność rosyjskojęzyczną, bez względu na deklarację przynależności narodowej. To właśnie język rosyjski pełni w Łatgalii podstawowe funkcje komunikacyjne, dominuje $\mathrm{w}$ mediach, publikacjach i na ulicy, spychając urzędowy język łotewski do poziomu urzędowości wymuszonej, czyli zła koniecznego. Ci, którzy z uporem bronią się przed tą dominacją rosyjskości, jak tutejsi rodowici Łatgalczycy, należą do zdecydowanej i marginalizowanej mniejszości. Łotysze z Rygi mówią wprost o rusyfikacji Łatgalii, czasem głośno powątpiewając w sensowność utrzymywania w obrębie państwa krainy, która kulturowo i ekonomicznie (najbiedniejszy region Unii Europejskiej) w takim stopniu odstaje od reszty ${ }^{1}$.

Nie zawsze tak było. Przyglądając się dzisiejszemu zawirowaniu tożsamościowemu i kulturowemu Łatgalii warto pamiętać, że chodzi o ziemię z ponad-

\footnotetext{
${ }^{1} \mathrm{~W}$ tekście niniejszym wykorzystuję i komentuję dane zawarte w rozdziale IV mojej książki (2008) pt. Nieobecna kultura. Przypadek Inflant Polskich. Kraków: Universitas, Kraków. 205-242 - „Projekt Inflanty”. Do niej także odsyłam wszystkich zainteresowanych literaturą przedmiotu i faktografią, służącą za podstawę niniejszych rozważań. Za możliwość wygłoszenia tego tekstu w charakterze wykładu monograficznego dziękuję Katedrze Ekokomunikacji na Wydziale Neofilologii UAM i jej kierownikowi, prof. Stanisławowi Pupplowi.
} 
osiemsetletnią historią zachodnioeuropejskiej kolonizacji, a wcześniej - $\mathrm{z}$ historią pogańskich księstw Łatgalów i Zelów. Pierwsze zamki obronne (Wolkenberg, Kryżbork) - wystawione głównie przeciwko księstwu nowogrodzkiemu i pogańskim Łotyszom oraz Litwinom - pochodzą jeszcze z XIII wieku. Zwłaszcza ruiny tego pierwszego, uporczywie sterczące $\mathrm{z}$ zalesionego wzgórza nad jeziorem Raźno ${ }^{2}$, znakomicie ilustrują dynamikę ówczesnej chrystianizacji i kolonizacji biorąc pod uwagę fakt, iż jest to zaledwie kilkanaście lub kilkadziesiąt lat po założeniu Rygi, odległej o dwieście pięćdziesiąt kilometrów. Ziemie te, atrakcyjne politycznie i gospodarczo jako styk kultury zachodniej i wschodniej oraz skrzyżowanie dróg handlowych, stanowiły przez osiem wieków pole nieustannych działań wojennych. Ich historię średniowieczną wypełniają opisy okrutnych walk chrześcijan z poganami, niemieckich rycerzy Zakonu Krzyżacko-Inflanckiego z księstwami ruskimi, bratobójczych walk pomiędzy plemionami bałtyckimi, a także krwawych konfliktów o dominację sił kolonizacyjnych Zachodu: papieskich biskupów i krzyżacko-inflanckich komturów ${ }^{3}$. Upadek średniowiecznego państwa zakonnego w Inflantach nastąpił głównie z powodu włączenia się do gry nowych mocarstw w Europie północno-wschodniej: carskiej Moskwy, Szwecji oraz nowopowstałej Rzeczpospolitej Obojga Narodów. Trwające niemal dwa wieki pomiędzy tymi państwami walki, zwane wojnami północnymi, doprowadziły do przejęcia przez Rosję kontroli nad całym terytorium Inflant i przyczyniły się późniejszej rusyfikacji Pribaltiki, której polityczne, społeczne i kulturowe skutki możemy obserwować do dzisiaj.

Włączenie się Rzeczpospolitej do wielkiego planu podboju inflanckich terytoriów nastąpiło z powodu tzw. inkorporacji Inflant, której datę ustala się na 28 listopada 1561. Tego dnia w Wilnie pomiędzy ostatnim mistrzem Zakonu Krzyżacko-Inflanckiego, Gotardem Kettlerem, a namiestnikiem królewskim, Mikołajem Radziwiłłem, podpisany został układ (tzw. pacta subjectionis) przypieczętowujący oddanie się znacznej części Inflant (bez Estonii) pod opiekę Polski. Określenie ,inkorporacja Inflant” dobrze oddaje całą złożoność owego aktu, w którym ziemie inflanckie przyłączone zostały do Rzeczpospolitej Obojga Narodów, a właściwie wchłonięte przez nią, czemu następnie przez ponad dwieście lat usiłowały zaprzeczyć, podkreślając swoją odrębność.

\footnotetext{
${ }^{2}$ Wielokulturowość tamtych terenów przejawia się również w multiplikacji toponomastycznej, czyli że każda miejscowość, rzeka, jezioro mają nazwy w kilku językach, wszystkie nadal w aktywnym użyciu. Tutaj używam tylko nazw polskich, a zainteresowanych odsyłam do indeksów zawartych w moich poprzednich ,inflanckich” publikacjach: Gustaw Manteuffel. 2007. Zarysy $z$ dziejów krain dawnych inflanckich, red. Krzysztof Zajas. Kraków: Universitas; Manteuffel, G. 2009. Pisma wybrane, t. I, Inflanty Polskie. Listy znad Bałtyku, red. Krzysztof Zajas. Kraków: Universitas.

${ }^{3}$ Mówi o tym obszernie pierwsza część Gustawa Manteuffla Zarysów z dziejów krain dawnych inflanckich..., a także rozdział Niemiecka historia Inflant mojej książki Nieobecna kultura.
} 
W układach i przywilejach z tamtego czasu tkwi jedna z przyczyn interesującej nas permanentnej wielokulturowości późniejszego województwa inflanckiego, które pozostało przy Rzeczpospolitej po przegranych wojnach północnych jako tzw. Inflanty Polskie. Teren ten, obejmujący cztery powiaty: dyneburski, lucyński, rzeżycki i marienhauski, zamieszkiwali niemiecko-inflanccy ziemianie, łotewscy (łatgalscy), litewscy, białoruscy i ruscy chłopi, rosyjscy i żydowscy kupcy, a po inkorporacji doszli również polsko-litewscy panowie oraz polscy i litewscy chłopi. Jeżeli do tego dodamy niewielkie grupy etniczne Estończyków, Tatarów, Ormian itp., otrzymamy typowo pograniczną, wielokulturową mieszankę, w której trudno mówić o jednej dominującej nacji. Tak było na wszystkich pograniczach kresowej Rzeczpospolitej, natomiast w Inflantach szczególną rolę kulturotwórczą odegrało niemiecko-inflanckie ziemiaństwo. W państwie zakonnym w Inflantach była to klasa społeczna wysoko uprzywilejowana, $\mathrm{z}$ tego prostego względu, że sama dla siebie ustanawiała prawa i obowiązki. Kiedy doszło do negocjacji z Polską na temat inkorporacji, jednym $\mathrm{z}$ ważnych jej argumentów było zachowanie dotychczasowej pozycji oraz zrównanie w prawach z polską szlachtą. Król Zygmunt August zgodził się na jedno i drugie, i tym sposobem szlachta niemiecko-inflancka wskutek połączenia z Rzeczpospolitą stała się pod koniec XVI wieku najbardziej uprzywilejowaną klasą w Europie. Przez następne dwieście lat jej główne polityczne zabiegi polegały na umacnianiu wpływów w Inflantach Polskich i zachowaniu owych fantastycznych przywilejów.

Włączenie w obręb republiki sarmackiej ziemian niemiecko-inflanckich, na podstawie nieprecyzyjnych warunków i osobistych deklaracji polskiego króla, stworzyło kapitalną sytuację, w której Inflantczycy zarazem byli i nie byli obywatelami Rzeczpospolitej. Z jednej strony podkreślali swoją lojalność wobec dworu w Warszawie oraz sejmu, zarówno koronnego jak i litewskiego, z drugiej natomiast - zaznaczali swoją odrębność i powoływali się na gwarancje praw do języka urzędowego, wyznania i własnego porządku legislacyjnego (Sprache, Glaube, Recht). Skutek był taki, że deklarująca swoją polskość szlachta inflancka mówiła po niemiecku i francusku, wyznawała protestantyzm i funkcjonowała na podstawie własnej, lokalnej jurysdykcji, starając się odróżniać zarówno od szlachty koronnej, jak też litewskiej ${ }^{4}$. Przez pewien czas forsowano nawet określenie „Rzeczpospolita Trojga Narodów” uważając, że jest to w istocie państwo polsko-litewsko-inflanckie. Tak przynajmniej uważali sami Inflantczycy, pozorując polonizację i katolicyzację, podczas gdy Litwini uważali ich za część

\footnotetext{
${ }^{4}$ Gdy przedstawiciel jednego z najlepszych rodów polsko-inflanckich, Jan Andrzej Plater, przeszedł w roku 1695 (sic!) z protestantyzmu na katolicyzm, król polski tak się ponoć ucieszył z tej konwersji, że natychmiast z radości mianował go wojewodą inflanckim. Musiał to być zatem przypadek dosyć odosobniony i spektakularny, z którego mamy prawo wnosić, że większość ówczesnej szlachty inflanckiej niemieckiego pochodzenia była nadal protestancka.
} 
Wielkiego Księstwa Litewskiego, natomiast szlachta koronna - za inflanckich Niemców.

Obok, a właściwie naprzeciw szlachty niemiecko-inflanckiej, znalazła się w Inflantach polskich szlachta polsko-litewska, traktująca nowe nabytki Rzeczpospolitej raczej jako łup wojenny, niż jako część federacyjnego państwa. $\mathrm{W}$ istocie, część terytorium stanowiły królewszczyzny, przejęte wskutek wojen ze Szwecją i z Rosją, na których osiedlani byli zasłużeni weterani. To głównie dzięki uprawianej przez nich propagandzie stara szlachta niemiecko-inflancka miała problemy z zaświadczeniem swojej lojalności wobec Warszawy. Udowadnianiem tej lojalności zajmowała się przez z górą trzysta lat. Same Inflanty Polskie i sąsiednia Kurlandia - przypadająca Polsce jako lenno z rodem Kettlerów na tronie - stały się synonimem dziwności, nieokreślonej tożsamości i podejrzanych aspiracji, a w literaturze przedmiotem kpin. Nawet zupełni ignoranci spytani o Inflanty, przytaczają rzekomą anegdotę z Trylogii Sienkiewicza o tym, jak to Zagłoba „sprzedawał Inflanty”, zdradzając ignorancję podwójną, i wobec krainy, i samego Sienkiewicza. Naprawdę było tak, że w III tomie Potopu, podczas oblężenia Zamościa, Zagłoba radzi staroście zamojskiemu, by w odpowiedzi na ofiarowanie mu województwa lubelskiego (którym już rządził) podarował królowi szwedzkiemu Niderlandy (o które Szwecja bezskutecznie walczyła w wojnie trzydziestoletniej). Natomiast kilka rozdziałów dalej Zagłoba żąda od Szwedów Inflant i pieniędzy za pokój: „Niech ustąpią Inflanty i miliony pozwolą, darujem ich zdrowiem" (t. III, rozdz. VII). Jakim cudem obie te anegdoty złączyły się w jedną, mylną, trudno powiedzieć, świadczy to wszakże o nieszczęśliwej i permanentnej nieokreśloności inflanckiej krainy, która nawet w żartach nie zdołała zachować swojej tożsamości.

$* * *$

Już na samym początku polskiej historii Inflant powstała kwestia fundamentalna związana z pytaniem, co właściwie i do czego zostało przyłączone. Świetnie to widać w pierwszej próbie uchwycenia substancji politycznej i geograficznej regionu, podjętej już w sześć lat po inkorporacji, czyli w roku 1567. W Królewcu, w drukarni Daubmanna, ukazała się niewielka książeczka pod symptomatycznym tytułem: Wszystkiey Lifflandczkiey ziemie, iako przed tym sama w sobie byla, krótkie a pożyteczne opisanie, której głównym celem było uobecnienie czegoś, co wprawdzie zostało właśnie przyłączone do Rzeczpospolitej, ale co w powszechnej świadomości nie istnieje. Jej autorem był Marcin Kwiatkowski z Rożyc, zwany również Quiatkoviusem (? - 1588), pisarz reformatorski, adaptator Konfesji Augburskiej Melanchtona na gruncie polskim (1561), thumacz Ksiażeczek rozkosznych a wielmi pożytecznych o poczciwym wychowaniu... Pietra Paula Vergerio (1564), który swoim humanistycznym wykształce- 
niem służył dworowi książęcemu w Prusach. Z dworem tym związana jest również naczelna intencja inflanckiej publikacji, mająca posłom królewskim w Warszawy przybliżyć wieści o właśnie inkorporowanych ziemiach, podkreślając ich wartość i ważność dla polskiej polityki. W umieszczonej na początku dedykacji Kwiatkowski przyznaje, iż wiadomości o Inflantach zaczerpnął z książek i relacji „statecznych ludzi”, i na tej podstawie dopiero o „tej Lifflandckiey ziemi szersze i dostateczniejsze językiem polskim książeczki uczynił"5. Inaczej mówiąc Marcin Kwiatkowski, jak na rasowego humanistę przystało, zajmował się kompilacją, adaptacją i imitacją cudzych tekstów na potrzeby doraźnych celów wydawniczych i politycznych, załatwiał zatem jakiś ważny interes pruskiego księcia Albrechta, którego wówczas był dworzaninem. Adresatami uniżonej dedykacji we wstępie byli posłowie królewscy. O jaki zatem interes mogło chodzić?

Rządzący w Królewcu ród Hohenzollernów nienajlepiej czuł się w roli lennika Polski i w jego dalekosiężnych planach majaczyła próba zjednoczenia Brandenburgii, Prus i Inflant w jeden wielki organizm państwowy pod ich berłem. W tym kierunku szły główne zabiegi dyplomatyczne pruskiego dworu, a Polska odgrywała $w$ nich rolę zarówno najważniejszego sprzymierzeńca, jak i zawady na drodze do sukcesu. Inaczej mówiąc mogło chodzić o to, by namówić Polaków do militarnej interwencji w Inflantach i wyparcia stamtąd Moskwy, a w dalszej przyszłości o przejęcie terytorium za pomocą dyplomatycznych intryg. Ślad takiego myślenia znajdujemy w Diariuszu postów inflanckich z roku 1561, powstałym podczas negocjacji inkorporacyjnych i świadczącym o ciekawym skrzyżowaniu interesów politycznych wokół naszej krainy. Dokument ten, przytoczony w całości przez Gustawa Manteuffla, stanowi relację $\mathrm{z}$ poselstwa inflanckiego na dwór królewiecki, w celu rozpoznania warunków politycznych i ekonomicznych wcześniejszego przyłączania Prus do Polski. Wysłannicy mistrza Gotarda Kettlera chcieli się dowiedzieć, na co mają uważać przy sporządzaniu pactum subjectionis, jakie zapisy są dla nich korzystne, a jakich powinni unikać. Dłuższy cytat z tego dokumentu pokaże nam ciekawy kontekst dyplomatyczny, włącznie z ukrytym interesem Hohenzollernów:

Jakoż, sądzi on [Kanitz - sekretarz księcia Albrechta], iż poddanie się Polsce mogłoby zostać tak przeprowadzonem, aby bez szkody dla króla polskiego, było jednakże z korzyścią dla hermistrza i wszystkich krain inflanckich, a mianowicie: w pactum subjectionis powinno być wyrażone, że król polski został od cesarstwa rzymskiego uproszo-

\footnotetext{
${ }^{5}$ Korzystam tu z fotokopii oryginału, dostępnej w Łotewskim Państwowym Archiwum Historycznym w Rydze, LVVA 6984, t. I, z. 3, nr 1. Więcej informacji o Marcinie Kwiatkowskim znajdzie czytelnik w pracy Kwiatkowski, M. 1997. Pisma. Edycje królewieckie, red. Marian Pawlak. Bydgoszcz: Wydawnictwo Wyższej Szkoły Pedagogicznej w Bydgoszczy.
} 
ny, by zagrożone od Moskwy kraje inflanckie obronić, że taka obrona cudzego kraju bez własnych korzyści jest nader kosztowną i uciążliwą dla Jego Królewskiej Mości i że tego rodzaju bezinteresowna opieka, nie mogąc być bardzo groźną dla wiecznego wroga (...), staje się bez korzyści dla Inflant, przeto kraje inflanckie poddają się całkowicie królowi polskiemu, jako swemu dziedzicznemu panu (...), pod tym wszakże warunkiem, że gdyby w przyszłości cesarstwo rzymskie chciało zwrócić królowi polskiemu wszystkie koszta teraźniejszej obrony ziemi inflanckiej i koszta późniejsze utrzymania całości jej granic, to Inflanty do cesarstwa napowrót zwrócone zostaną i owa „subjekcya” nie stanie zgoła na przeszkodzie ${ }^{6}$.

Po pierwsze, sekretarz księcia pruskiego sugeruje, że Inflanty nadal należą do Świętego Cesarstwa Rzymskiego Narodu Niemieckiego, które reprezentuje na tych terenach dynastia Hohenzollernów. Po drugie, że inkorporacja ma nastąpić na prośbę Cesarstwa, a przyłączone ziemie stają się własnością dziedziczną polskich królów. Po trzecie jednakże, jeśli będzie taka wola, Cesarstwo może odkupić $\mathrm{z}$ powrotem Inflanty od Polski, zwracając jej poniesione wskutek wojen z Moskwą koszty. Na zdrowy rozum biorąc, byłoby to właściwie coś w rodzaju ,wypożyczenia” Inflant Rzeczypospolitej, aby ta mogła skutecznie oczyścić je z najeźdźców, z możliwością zwrotu po ustaleniu wysokości odszkodowania. Trudno się zatem dziwić, że w pojęciu sejmu koronnego kraina ta przypadała Polsce, zarazem pozostając pod obcymi wpływami i mogąc od niej w każdej chwili odpaść.

Książeczka była typowym dziełem XVI-wiecznym również w tym sensie, że odwoływała się do kosmograficznego modelu jako obowiązującego wzorca pisania naukowego. Marcin Kwiatkowski z Rożyc próbował opisać całość Inflant na wzór „inszych Kosmography”, z których korzystał. Całość ta, nawiasem mówiąc, nie wygląda zachwycająco. Dokonując rozeznania we wpływach militarnych wylicza, że w rękach Moskwy znajdują się 22 zamki, w rękach Szwedów 5, księcia holsztyńskiego Magnusa 4, a także 11 zamków zburzonych i opuszczonych, pomijając zamki biskupie oraz te w Kurlandii. Obce wojska zajmują zatem niemal połowę Inflant. Ostrze propagandy autora Wszystkiey Lifflandczkiey ziemie... skierowane było przeciwko Moskwie, której przypisane zostały cechy najgorsze:

Tu nie oznajmuję ani wypisuję komór, to jest dworów, ani mniejszych urzędów, którą wszystkie ziemice ze wszystkimi kluczami, starostwy, miasty, zamkami, dworami i wszelakimi urzędami, tak wielkimi jako małymi, zapamiętały Moskwicin, naprzeciw przykazaniu Bożemu i prawu świeckiemu, posiadł. A Panie Boże daj, o co się mamy ustawicznie modlić, i sami się do tego z pilnością przyczynić, iżeby jego Królewska M.

\footnotetext{
${ }^{6}$ Manteuffel, G. 2013. Pisma wybrane, t. II, Portrety miast inflanckich. Pieśni gminne, red. Krzysztof Zajas. Białystok: IBnDKE. 305.
} 
tego gwałtownika prawa Bożego i Ludzkiego, a rozlewcę niewinnej krwie chrześcijańskiej, mógł potłumic ${ }^{7}$.

W dalszych partiach tekstu autor skrupulatnie wypisuje wszystkie krzywdy wyrządzane przez Rosję w Inflantach, wpisując się tym samym w retorykę zachodniej rusofobii, bardzo wówczas - w latach kwitnącej reformacji i paraliżującego lęku przed carem Iwanem IV Groźnym - popularnej. Widać również, jak zależy mu na przekonaniu posłów królewskich do misji oswobodzenia Inflant spod obcego jarzma, które od kilku lat stanowią jej integralną część.

$\mathrm{Z}$ drugiej strony widoczna jest również tendencja odwrotna. Inflanty zostały przedstawione w maleńkiej królewieckiej kosmografii jako odrębna całość, byłe państwo zakonne, wewnętrznie zróżnicowane, osobne jednak wobec każdego z najeżdżających je imperiów. Kwiatkowski mówi o jego granicach, wylicza poszczególne krainy i jednostki terytorialne, do pewnego stopnia ignorując fakt, że politycznie państwo to przestało właśnie istnieć. Atrakcyjność inflanckich ziem dla Polaków polegać miała głównie na ich bogactwie i rozległości, ale nie na tym, że stanowią integralną część Rzeczpospolitej. O tym należało warszawskich posłów dopiero przekonać i w tym celu dworzanin pruskiego księcia napi sał kosmograficzną broszurę.

Kolejny ciekawy obrys całości ziem inflanckich pojawił się dwa stulecia później, a dokładnie w roku 1750, kiedy to kasztelan inflancki, Jan August Hylzen (1702-1767), wydaje dzieło pod barokowym tytułem Inflanty $w$ dawnych swych $i$ wielorakich aż do wieku naszego dziejach $i$ rewolucjach; $z$ wywodem godności i starożytności Szlachty tamecznej, tudzież praw i wolności z dawna i teraz jej służacych zebrane i Polskiemu światu do wiadomości w Ojczystym języku podane przez, Jaśnie Wielmożnego Jmci Pana Jana Augusta Hylzena, KASZTELANA inflanckiego, STAROSTE sqdowego brastawskiego, MARSZALKA na ów czas W. Trybunalskiego W. X. Lit. Roku Pańskiego 1750, dnia 2 stycznia w Wilnie w drukarni J. K. M. Akademickiej Societatis Jesu. O ile Marcin Kwiatkowski był królewieckim ignorantem, korzystającym głównie z cudzych opracowań i relacji, o tyle Hylzen pisał z pozycji zasiedziałego ziemianina niemiecko-inflanckiego oraz polsko-inflanckiego, które to dwa określenia nie wykluczają się, a uzupełniają. Pochodził ze starego rycerskiego rodu de Hülsen i zaledwie jego ojciec dokonał spolszczenia nazwiska, oczywiście w celach autoreklamy na dworze warszawskim, gdzie starał się o zachowanie sukcesji ziem inflanckich dla synów. Majątki rodowe leżały na terenie województwa inflanckiego, czyli Inflant Polskich, które zawar-

\footnotetext{
${ }^{7}$ LVVA 6984, t. I, z. 3, nr 1, 8-9.
} 
tą w nazwie polskość musiały od czasów Zygmunta Augusta wciąż na nowo zaświadczać.

Przyglądając się tytułowi łatwo odnajdziemy w nim wszystkie ważniejsze składniki Hylzenowskiej argumentacji: dzieje odrębne Inflant, zasiedziałość lokalnej szlachty i związane z tym odwieczne prawa, Polacy jako adresaci publikacji oraz język polski jako deklaracja patriotyzmu i środek na dotarcie do odbiorcy. Niebanalnym elementem wywodu były godności i urzędy autora, umieszczone na stronie tytułowej. Chodziło o to, by z historii i kulturowej odrębności Inflant Polskich uczynić argument prawny i polityczny, czego wsparciem miało być przywołanie także sądowej funkcji Hylzena.

Wyłuszczony we wstępie cel ogromnej i nieco dziwacznej publikacji został sformułowany następująco:

Takowa wielorakość namnożonych praw Inflantskich pokąd porządnej i dowodnej nie było informacji z historii tejże Prowincji pochodzącej; kiedy, z jakich przyczyn i jakowym sposobem jedne ustały, drugie nastąpiły, zawiłą sprawowała trudność do pojęcia i rozeznania onych. Przeto nie masz czemu się dziwować (...), że kiedy wszystkie dobra Szlacheckie, które przedtem za Krzyżaków lennym szły prawem, na dziedziczne i wieczyste od Króla Zygmunta Augusta przy inkorporacji Inflant do Rzeczypospolitej wyraźnie są zamienione, a zatem nie innym, tylko dziedzicznym prawem powinny być dzierżane; z tym wszystkim przez niewiadomość esencjalnego tego prawa, po większej części za otrzymaniem niesłusznym przywilejów na lenne lub dożywotnie poszły dzierżawy ${ }^{8}$.

Jan August Hylzen znany był ze swojej pazerności na dobra, nie tylko inflanckie, a zatem monografia Inflant była mu potrzebna również do załatwienia interesu, nieco jednak odmiennego od interesów pruskiego dworu w XVI w. Chodziło o przypomnienie Polakom, że kraina ta została do Rzeczpospolitej przyłączona dobrowolnie, za powszechną aprobatą jej wolnych obywateli, a zatem nie wskutek podbojów i prawa nadane tamtejszej szlachcie w Privilegium Sigismundi Augusti nadal obowiązują. Więcej - idą przed prawami późniejszymi, nadawanymi nowoosiadłej szlachcie polsko-litewskiej na dobrach królewskich. Księga napisana została po to, by przypomnieć obowiązujące prawa, czyli de facto ustanawiać je na nowo, na swoją korzyść.

$\mathrm{Za}$ argumentacją Hylzena stoi konflikt pomiędzy starą i nową szlachtą polsko-inflancką, przy czym ta pierwsza jest nieustannie podgryzana przez tą drugą jako „niemiecka”. Przybywający z Rzeczpospolitej ziemianie z nadaniami od króla traktowali Inflanty Polskie jako zdobycz wojenną i zajmowali terytoria, które zdaniem autora Inflant im się nie należały (indygenat). Możemy sobie

\footnotetext{
${ }^{8}$ Jan August Hylzen, 1750. Inflanty... Wilno: W Drukarni J.K.M. Akademickiey Societatis Jesu. A3-A4. Korzystałem z egzemplarza udostępnionego mi przez Bibliotekę Miejską w Rydze.
} 
wyobrazić, że polemizował on z odmienną interpretacją stanu politycznego województwa inflanckiego, zgodnie z którą ci z nowymi nadaniami również są szlachtą polsko-inflancką, więc mają równy tytuł do gruntów i urzędów. Podłoże konfliktu miało charakter legislacyjny i ekonomiczny (interes), dlatego też starosta sądowy bracławski postanowił uporządkować stan prawny pisząc historię krainy po swojemu. Księga jest nie tyle spisaniem dziejów Inflant Polskich, ile dowodem w inflanckiej sprawie tutejszej arystokracji niemiecko-bałtyckiego pochodzenia:

Naycelnieysze Domów y Imion zaszczyty pochodzą y wyznaczają się naybardziey z starożytności y zasług. Byłoby to grubey w politycznych rzeczach niewiadomości podlegać cenzurze, nie przyznać Rycerstwu Krzyżackiemu: że będąc sam z nayprzednieyszych Rycerstw Chrześciańskich, jednym był on, oraz y podziśdzień jeszcze jest złożonym z wyboru dawnych y zacnych Domów ${ }^{9}$.

Aby ustanowić wyraźną granicę pomiędzy zasiedziałymi Inflantczykami pochodzenia niemieckiego, a szlachtą napływającą do Inflant Polskich po roku 1561, nasz autor posłużył się dosyć ryzykownym argumentem o wyższości Krzyżaków nad Polakami i dla uzasadnienia swego wywodu przywoływał mnóstwo dokumentów. Jego dowodowa zapamiętałość doprowadziła do tego, że Inflanty... mają bardzo nierównomierną i przez to dziwaczną kompozycję. Po pełnym pouczeń i oburzenia na polską ignorancję wstępie przychodzi kilkaset stron odpisów rozmaitych aktów prawnych i przywilejów, poświadczających słuszność Hylzenowej argumentacji. Tym samym księga nie historią, nie jest też kroniką, chociaż autor lubi nazywać siebie kronikarzem. Przedstawia dowód w sądowej sprawie o pierwszeństwo w obejmowaniu urzędów inflanckich, a fundamentem tego dowodu jest podkreślenie odrębności Inflant Polskich, której faktyczni gospodarze są i zarazem nie są Polakami. Widoczne to jest w dydaktycznym zakończeniu wstępnego wywodu kasztelana:

$\mathrm{Na}$ koniec, z jakiego powodu część większa Inflant z nienagrodzoną dla Rzeczypospolitej szkodą Szwedom się podała? Zbawienną stąd na przyszłe czasy weźmiemy naukę, żebyśmy do takich awulsji i ujmy krajów Rzplitej przez popełnione w politycznym rządzie solecyzmy, jak się z Inflantami stało, podobnych nie nastręczali okazji ${ }^{10}$.

Los Inflant ma być również przestrogą dla Polaków, by trochę rozsądniej i z szerszymi horyzontami uprawiali swoją politykę wobec „krajów Rzplitej”, co możemy przełożyć na nasze wielokulturowe kategorie, jako apel o poszanowanie regionalnej odmienności. Hylzen podjął się trudnej próby wytłumaczenia obywatelom sarmackiej republiki, że stara arystokracja niemieckiego pochodze-

\footnotetext{
${ }^{9}$ Hylzen, J.A. Inflanty..., cyt. za: Manteuffel, G. Pisma wybrane, t. I. 49.

${ }^{10}$ Hylzen, J.A. Inflanty. A2.
} 
nia jest wierna i lojalna wobec Korony polskiej, posiada jednak swoją specyfikę kulturową i historyczną, wymagającą odpowiedniego potraktowania. Słychać tu głos obywatela, który pomieszkując w stolicy (Hylzen wystawił wielki pałac w Warszawie, nieopodal Zamku Królewskiego, znany później jako pałac Mostowskich), musi posłom i dostojnikom tłumaczyć, co to znaczy pochodzić z Inflant Polskich, leżących gdzieś na „kresach kresów”. Dwa wieki po przyłączeniu do Rzeczpospolitej w powszechnym (ignoranckim) odbiorze stanowily one nadal zbyteczną i śmieszną krainę ubi leones, z której „inności” trzeba się panom sarmatom thumaczyć.

$$
* * *
$$

W przypadku kultury dawnych Inflant Polskich mamy do czynienia z dosyć rzadkim jak na naszą historię zjawiskiem, czyli polonizacją Niemców. Wprawdzie nazywanie starej arystokracji inflanckiej „Niemcami” wymaga zastrzeżeń (byli to Bałto-Niemcy, od wieków osiadli na tamtych ziemiach i stanowiący coś w rodzaju rycerskiej skamieliny), niemniej w powszechnym odbiorze uchodzili za przedstawicieli kultury niemieckiej i luterańskiego wyznania. Bronili swojej osobliwej tożsamości inflanckiej przez cały okres przynależności do Rzeczpospolitej Obojga Narodów, przechodząc pod władzę carskiej Rosji dopiero po pierwszym rozbiorze. Udało im się przetrwać $\mathrm{z}$ tą swoją odrębnością do począt$\mathrm{ku}$ XIX w., kiedy to wraz $\mathrm{z}$ wolnościowymi powiewami z Zachodu i nową, romantyczną definicją wolności w kulturze polsko-inflanckiej aktywizuje się idea patriotyzmu polskiego. W ciągu dwóch wieków polskiej dominacji nasi Inflantczycy bezustannie powoływali się na swoje przywileje (Sprache, Glaube, Recht) i dopiero wraz z nastaniem zwierzchności rosyjskiej doszli do wniosku, że są Polakami. Nie nastąpiło to od razu, czasy napoleońskie i nawet powstanie listopadowe mają stosunkowo łagodny przebieg w Inflantach (choć to stamtąd przychodzi do Litwy wojowniczka-symbol, Emilia Plater), a problem zaostrza się wraz ze wzmożoną rusyfikacją dawnych kresów wschodnich Rzeczpospolitej.

Gustaw Manteuffel (1832-1916) miał w kwestii uobecniania Inflant Polskich zadanie jeszcze trudniejsze, niż jego poprzednicy. Kiedy w roku 1969 wydawał w Rydze po niemiecku swoją pierwszą monografię Polnisch-Livland, województwo inflanckie nie istniało już od niemal stu lat, a od dramatycznego powstania styczniowego minęło lat pięć. Tragiczny epizod powstańczy, zakończony spektakularnym rozstrzelaniem jednego z lokalnych przywódców, Leona Platera, w twierdzy dyneburskiej (jest tam dzisiaj tablica upamiętniająca to zdarzenie), wywołał u Rosjan furię i przyczynił się do wzmożenia rusyfikacji i prześladowań Polaków. Zażywająca dotychczas względnego spokoju i wygody życia dworskiego na inflanckich kresach szlachta padła ofiarą represji w postaci rujnu- 
jących kontrybucji, podatków i sekwestracji majątków, skutkiem czego masowo uciekała do Rygi, Wilna i dalej na Zachód, do innych zaborów. Życie polskiego dworu w Inflantach zamarło, a wraz z nim poczucie przynależności kulturowej i cywilizacyjnej wspólnoty kresowych ziemian. Swoją niewielką książeczką Manteuffel próbował zachować w pamięci krainę właśnie odchodzącą bezpowrotnie w historyczną przeszłość.

Pisał po niemiecku, ponieważ po polsku nie umiał. Języka polskiego uczyła go matka, zdeklarowana katoliczka, ale nie czuł się w nim pewnie i w piśmie posługiwał się niemczyzną. Sytuacja uległa zmianie, kiedy na jego publikację entuzjastycznie odpowiedział Józef Ignacy Kraszewski. Namówił Manteuffla do wydania książki po polsku, i po kilku latach bezskutecznych poszukiwań dobrego tłumacza autor postanowił dzieło przełożyć samodzielnie. Skutkiem tej aktywności były wydane w 1879 r. w Poznaniu Inflanty Polskie, poprzedzone ogólnym rzutem oka na siedmiowiekowa przeszlość calych Inflant, znacznie rozbudowane $\mathrm{w}$ stosunku do niemieckiego oryginału i uzupełnione tablicami genealogicznymi oraz wykazem wszystkich miejscowości i majątków, kościołów, kaplic, cerkwi, zborów, wraz z obecnymi i byłymi właścicielami. Nie była to praca w ścisłym sensie historyczna; Manteuffel, wzorem poprzedników, próbował zbudować pełny obraz krainy, zbierając wiedzę z zakresu geografii, historii, etnografii, ekonomii, genealogii, geologii i archeologii, historii sztuki i literatury. Tworzył syntezę, mającej nie tyle oddać stan faktyczny (choć i taka ambicja stała za tą próbą), co stworzyć złudzenie odrębnego istnienia krainy, która właśnie przestała istnieć. Wsparciem dla tego zamierzenia miało być uruchomienie całego dostępnego aparatu badawczego ówczesnej nauki.

Manteuffel zaczynał jako badacz folkloru wschodniołotewskiego, czyli łatgalskiego, zapisując dawne chłopskie pieśni w oryginalnym języku i łacińskim alfabecie. Dzięki temu dzisiaj funkcjonuje w historii Łotwy jako jeden z fundatorów jej kultury, któremu na nagrobku w rodzinnych Drycanach napisano: „Przyjacielowi Łotyszy”. Język polski był więc trzecim, a właściwie czwartym jego językiem pisanym (po niemieckim, górnołotewskim i łacinie), do swojego patriotyzmu polskiego dochodził więc dosyć okrężną drogą. Być może przez to właśnie jego późniejsze deklaracje przywiązania do kultury polskiej i katolickiego Kościoła mają szczególną wagę.

U podstaw inflantologicznej pracy Gustawa Manteuffla widać podobną jak u poprzedników trudność, to znaczy świadomość zaczynania od początku. Już na wstępie, podchodząc do tematu Inflant Polskich, powtarza po Kwiatkowskim i Hylzenie zarzut o powszechnej nieznajomości rzeczy:

Wiadomości rzadko napotykane o tej części kraju, należącego niegdyś do rycersko-zakonnego państwa, w obszerniejszych nawet dziełach, traktujących o Nadbałtyckich prowincjach, nie tylko że nie rozwiązują wielu ważniejszych kwestii, ale nadto, pod 
względem geograficznym, statystycznym, etnograficznym i historii rozwoju umysłowego powtarzają szereg grubych błędów. Obałamucony czytelnik nie jest w stanie $\mathrm{z}$ dzieł tych dowiedzieć się, gdzie kraj ten leży, jaki jest jego ustrój, kto go zaludnia ${ }^{11}$.

Ignorancja jest wszechobecna, ogarnia nie tylko powszechnego odbiorcę, ale również autorów dzieł dotyczących jego rodzinnego kraju. Trzeba podjąć na nowo trud ustanawiania ułomnego bytu Infant Polskich. Chęć wyjaśniania błędów i prostowania przekłamań w cudzych publikacjach wydaje się jednak $\mathrm{w}$ argumentacji autora jedynie pretekstem, ponieważ nie wiadomo właściwie, kto i w jakim celu miałby poznawać „ustrój” kraju, którego formalnie nie ma. Jak kiedyś Hylzen, tak teraz Manteuffel musi tworzyć substancję inflanckiej krainy z niczego, a ściślej rzecz biorąc - z Hylzena oraz niczego. Wprowadza jednak ciekawe i z punktu widzenia badań kulturowych istotne modyfikacje, uzupełnia bowiem swój opis o charakterystyki poszczególnych grup etnicznych zamieszkujących Inflanty Polskie ( za co chwali go Kraszewski), w charakterystycznej zresztą kolejności. Najpierw pojawia się ludność miejska - Polacy, Żydzi, Rusini, Rosjanie i Niemcy, następnie ludność wiejska - Łotysze, Polacy (właściciele), a pomiędzy nimi rozsiani tu i ówdzie Estowie, Litwini, starowiercy-Rosjanie, polscy chłopi... Dla świeżo nawróconego na polskość i katolicyzm Manteuffla charakterystyczny jest zabieg usunięcia na margines Niemców inflanckich. Sens tego zabiegu lepiej stanie się widoczny gdy uświadomimy sobie, że zarzut niekompetencji w powyższym cytacie skierowany jest głównie przeciwko historiografii i publicystyce Niemców bałtyckich. Polacy wszak o Inflantach Polskich pisali niewiele. Manteuffel po prostu za jedno ze swoich najważniejszych zadań uznał stworzenie przeciwwagi dla historiografii niemiecko-bałtyckiej, która zawłaszczała cały region dla własnych politycznych i propagandowych celów. Manteuffel odpowiadał więc tendencją na tendencję, w ściślej rzecz biorąc - intencją polsko-katolicką na intencję niemiecko-protestancką. Ten spór narodowy i wyznaniowy ciągnął się od końca XVI w., czyli od czasów tzw. rozruchów kalendarzowych w Rydze w latach 1584-89. ${ }^{12}$ Istotnie, w historiografii Niemców bałtyckich Inflanty Polskie zasadniczo nie występują, a jeśli w ogóle, to jako ziemie zrusyfikowane i leżące poza granicami Inflant właściwych.

Ambitne usiłowanie Gustawa Manteuffla trafiało w pustkę, ponieważ w tamtych czasach - budzących się ruchów narodowowyzwoleńczych wśród Bałtów oraz narastających separacji nacjonalistycznych - żadna ze stron (nacji) nie była zainteresowana przypominaniem o dawnym udziale Polaków w historii tych ziem. Głównymi graczami na ówczesnej giełdzie politycznej były

\footnotetext{
${ }^{11}$ Manteuffel, G. Pisma wybrane, t. I. 25.

${ }^{12}$ Więcej na ten temat znajdzie czytelnik w pracy Anny Ziemlewskiej (2008) pt. Ryga w Rzeczypospolitej Polsko-Litewskiej (1581-1621). Toruń: Towarzystwo Naukowe w Toruniu.
} 
nacjonalizmy: rosyjski, niemiecki, łotewski, a dawne wpływy polskie traktowano jako żałosny kostium upadłego imperium sarmackiego. Jedynym faktycznym skutkiem książki Manteuffla było przypomnienie o „genetycznej” wielokulturowości Inflant, co wobec nacjonalistycznych mód nie mogło wówczas stanowić szczególnej atrakcji. Historiografia, jak wiadomo, odnosi sukcesy tylko wtedy, gdy służy polityce, a polskiej polityki wtedy nie było.

Gustaw Manteuffel najwidoczniej wyciągnął wnioski z tej lekcji i podejmując kolejną próbę uchwycenia specyfiki kulturowej Inflant odwołał się do paradygmatu lokalności. W Listach znad Battyku (1889) najwięcej miejsca poświęcił tak zwanym rdzennym mieszkańcom Inflant, czyli Łotyszom, Estończykom (Estom), Liwom, później także Rosjanom i Polakom. Zamiast polonocentrycznej perspektywy historycznej mamy bałtocentryczną perspektywę kulturową, z naciskiem na miejscowy folklor, architekturę i obyczaje łotewskich chłopów, ustną literaturę, szkolnictwo itd., obejmując swoją interdyscyplinarną działalność mianem „krajoznawstwa”. To w Listach znad Battyku można dostrzec pierwsze próby ogarnięcia wszystkich ziem inflanckich jednym wielkim projektem kulturowym, z podziałem na narody, języki, wpływy kolonialne i chrystianizacyjne, imperialne aspiracje. Niesatysfakcjonujący oddźwięk Inflant Polskich, która to książka „nieznajomości o tych ziemiach niegdyś polskich nie zdołała jeszcze całkowicie wyjaśnić"13, doprowadził Manteuffla do zmiany perspektywy z ciasnej, polsko-inflanckiej, na znacznie szerszą, ogólnobałtycką. Opowieść o dawnym państwie inflanckim i jego wielokulturowych pozostałościach wymagała umieszczenia całej tematyki w kontekście dziejów europejskich i wzmocnienia przez właściwy ogląd historyczny.

Taką - najpoważniejszą w dorobku Gustawa Manteuffla - próbą były Zarysy z dziejów krain dawnych inflanckich, pisane na przełomie lat 80. i 90. XIX w., nigdy za życia autora niewydane. Jej wyjściowym założeniem było:

...dostarczyć światłej publiczności polskiej zbioru najważniejszych przedmiotowo traktowanych faktów historii krain dawnych inflanckich. Nie jest praca niniejsza popularną w zwyczajnym tego słowa znaczeniu, bo nigdzie nie liczy się z pedagogicznymi i dydaktycznymi względami, przemawia tym samym językiem, którym by ściśle naukowe dzieło przemawiało; wszakże nie opatrzona pełnym aparatem przypisów objaśniających, do naukowości rościć nie może pretensji ${ }^{14}$.

Zarysy stanowią opus magnum naszego polsko-inflanckiego historyka. Usiłował on połączyć w nim wszystkie najważniejsze tendencje swej kulturotwórczej działalności, tworząc $\mathrm{w}$ efekcie kompendium wiedzy o przedmiocie nadal w jego przekonaniu nieznanym. Stąd liczne, niekiedy nawzajem sprzeczne funk-

\footnotetext{
${ }^{13}$ Manteuffel, G. Pisma wybrane, t. 1. 207.

${ }^{14}$ Manteuffel, G. Zarysy z dziejów krain dawnych inflanckich. 7.
} 
cje, jakie tekst ten miał do spełnienia. Po pierwsze, miał być całokształtem, który nie jest historią, lecz opowieścią (Manteuffel często używał określenie „opowieść" na swoją książkę). Po drugie, przynosił jedynie podręczne zestawienie podstawowych faktów w szeregu krótszych lub dłuższych „zarysów”. Po trzecie, badania historyczne na podstawie tekstów źródłowych. Po czwarte, pozbawiony systematyki wybór zdarzeń i faktów, w których autor $-\mathrm{z}$ braku innych opracowań - musiał polegać na sobie i własnych archiwach domowych. Po piąte wreszcie, Zarysy miały być sprostowaniem nagromadzonych w literaturze przedmiotu błędów i przeinaczeń, stanowiły zatem kolejną próbę zwalczania nieuczciwej, tendencyjnej historiografii niemieckiej (zwanej przez autora ,protestancką").

Poczucie autora, iż tworzy swoje dzieło z materii ulotnej, słabo istniejącej, ledwie umocowanej w poważnych badaniach naukowych, widoczne jest już w samej kompozycji Zarysów. Pierwsza część obejmuje średniowieczne dzieje Zakonu Krzyżacko-Inflanckiego oraz arcybiskupstwa ryskiego i biskupstw bałtyckich, uzupełnione o skrupulatne rejestry zwierzchników, władców, biskupów, łącznie z latami urzędowania. Im bardziej rzecz nieznana i nieobecna, tym więcej należy przywołać danych szczegółowych dla umocnienia jej naukowej reprezentacji, więc Manteuffel popada czasem w uciążliwe wręcz szczególarstwo, by uzasadnić cel i wagę swojej pracy. Podobnie jak jego poprzednicy ma świadomość tworzenia z niczego, dlatego argumentuje uporczywie, bez końca, powtarzając się i brnąc w nieistotne dygresje i anegdoty - wszystko po to, by o istnieniu czegoś tak efemerycznego jak historia i kultura Inflant przekonać nie tylko czytelników, ale i samego siebie. Druga część Zarysów przedstawia historię Inflant Polskich, Kurlandii z Semigalią, Ziemi Piltyńskiej, czyli wszystkich tych ziem, które w jakiejś formie pozostawały w związku z Rzeczpospolitą. Znowu więc na tendencję usuwania Inflant Polskich w niebyt przez historiografię niemiecko-bałtycką, odpowiada tendencją ich uwypuklania i wysuwania na pierwszy plan. Skłonność do prostowania nadużyć owocuje nadużyciem w drugim kierunku, całkiem zgodnie $\mathrm{z}$ narratywistyczną koncepcją historiograficzną w pismach Haydena White'a i Franka Ankersmita.

W Zarysach do głosu doszły jednak i inne problemy kulturowe autora, niewidoczne w poprzednich syntezach. O ile w Inflantach Polskich oraz Listach znad Battyku Gustaw Manteuffel wykonywał jeszcze przyjazne gesty pod adresem władz carskich, o tyle tutaj podboje rosyjskie w Pribaltyce przedstawione są w zdecydowanie negatywnym świetle. Kilkanaście lat postępującej rusyfikacji i antypolskiej polityki carskiej czasów Murawjowa wpłynęło na zaostrzenie stanowiska drycańskiego barona bardziej, niż bezpośrednie skutki powstania styczniowego, które dotknęły rodzinę Mantuefflów w stopniu znaczącym. Niechęć do Rosjan narasta u autora Zarysów wprost proporcjonalnie do wzmożonej rusyfikacji ziem bałtyckich, która przecież stawiała sobie cele dokładnie od- 
wrotne, czyli osłabienie i wyeliminowanie czynnika polskiego z historii i kultury tamtego regionu. Stosując zasadniczo perspektywę wielokulturową i stanowisko ekumeniczne, Manteuffel pozwala sobie w swojej najważniejszej syntezie na postawienie jednej ostrej granicy: pomiędzy Wschodem a Zachodem. Są to dwa światy, dwie nieprzystające do siebie kultury, niepasujące do siebie i niezgodne. Doszedł tu do głosu dyskurs kolonialny autora, ale i osobiste urazy, którym dał wyraz na przykład w księdze poświęconej Dorpatowi i Uniwersytetowi Dorpackiemu ${ }^{15}$.

Ta największa i najambitniejsza próba przywrócenia Inflantom odrębnego bytu historycznego i kulturowego nie tylko nie przyniosła zamierzonych efektów, ale i sama praktycznie nie zaistniała. Mimo wieloletnich starań autora Zarysy nie ukazały się drukiem, a rękopis na wiele dziesiątków lat zaginął. Został przeze mnie wydobyty w magazynów New York Public Library w 2006 roku, przepisany i podany do druku $\mathrm{z}$ komentarzem oraz towarzysząca mu interesującą historią, którą przedstawiłem we wstępie do tamtej publikacji. Tu dodam tylko tyle, że był to prawdopodobnie ostatni z czterech rękopisów, jakie sporządzał sam Manteuffel, poprawiany i uzupełniany przez niego o najnowszą bibliografię niemal do końca. Chciał pozostawić tekst, który jak najdłużej zachowa aktualność i tym samym pozwoli choć w szczątkowej i ułomnej formie zaistnieć Inflantom.

Borykając się z oporem wydawców i luminarzy nauk historycznych w sprawie Zarysów, ich autor konstruował inne jeszcze syntezy historii Inflant. W roku 1888 do Watykanu dotarł prezent od Inflantczyków dla papieża Leona XIII, na uczczenie półwiecza jego kapłaństwa, w postaci olbrzymiej księgi o wymiarach około $60 \times 48 \mathrm{~cm}$, oprawnej w białą skórę cielęcą z wybitym na niej wielkim krzyżem Zakonu Krzyżacko-Inflanckiego i herbem papieskim, zatytułowanej Terra Mariana (Ziemia Maryi). Pomysłodawcą, koordynatorem i jednym z głównych sponsorów przedsięwzięcia był Gustaw Manteuffel, który napisał także wstęp po łacinie i opatrzył komentarzem poszczególne karty $\mathrm{z}$ ilustracjami. Imponujące to dzieło powstało w jednym egzemplarzu i miało na celu przypomnienie papieżowi, że ziemie bałtyckie jeszcze w XII w. wieku zostało ofiarowane Najświętszej Marii Pannie i choćby z tego powodu należy o nich pamiętać, zwłaszcza teraz ( koniec XIX w.), gdy odpadają one od kultury zachodniej na korzyść barbarzyńskiego Wschodu. Oszałamiająca szata graficzna, na którą składało się 70 kolorowych kart z rycinami pałaców, ruin zamkowych, kościołów i pejzaży inflanckich, miała prezentować piękno i bogactwo

${ }^{15}$ Manteuffel, G. 1911. Z dziejów Dorpatu i bylego Uniwersytetu Dorpackiego. Warszawa: E. Wende i Sp. Tytuł zdradza tendencję: uniwersytet w Dorpacie utracił swoją tożsamość wraz ze zmianą nazwy na Uniwersytet Jurjewski i wymianą kadry, w większości niemieckiej, na rosyjską. Manteuffel za ten antyrosyjski atak został postawiony przed sądem, a wydawnictwo skonfiskowano. 
odległej dla rzymskiego biskupa krainy, jej wspaniałą rycerską przeszłość i późniejszy melancholijny upadek. Księga - zgodnie z polemiczną pasją naszego badacza - usiłowała zaprzeczyć stanowi faktycznemu, jakim była całkowita zależność Inflant od Moskwy, i podkreślić ich zachodnioeuropejskie korzenie, a także jeszcze raz powtórzyć swoją tezę o ich kulturowej odrębności. Idee Manteuffla znowu nie miały szans na upowszechnienie, skoro dzieło powstało w JEDNYM egzemplarzu i jest do dzisiaj przechowywane w Bibliotece Watykańskiej $^{16}$.

W swoich niezmordowanych poszukiwaniach kolejnych perspektyw narracyjnych dla historii i kultury dawnych krain inflanckich Gustaw Manteuffel skomponował jeszcze jedną syntezę, o podobnie kolonizacyjnym wydźwięku, ale odmiennym materiale faktograficznym. Cywilizacja, literatura $i$ sztuka w dawnej kolonii zachodniej nad Battykiem, wydana w roku 1896 we Lwowie, a następnego roku również w Krakowie, opierała się na zgromadzonych przez tego upartego kolekcjonera ciekawostkach inflanckich z zakresu historii sztuki, architektury i literatury. Tytułowa „dawna kolonia zachodnia” to jeszcze jedna nazwa ziem bałtyckich, które tym razem przedstawione są jako przyczółek Zachodu na Wschodzie, najdalej wysunięty bastion cywilizacji dawnego rycerstwa niemieckiego. Dyskurs kolonializmu został tu potraktowany z całą powagą, jego podstawowe wyznaczniki dokładnie odpowiadały potrzebom potomka dawnej arystokracji niemiecko-inflanckiej, szukającego uzasadnień i kulturowych potwierdzeń dla własnych perspektyw narracyjnych. Posługując się ilustracjami i rysunkami udowadniał, że wszelkie przejawy kultury i cywilizacji w krajach bałtyckich pochodzą z Europy Zachodniej. Starał się zatem udowodnić coś, co nawet dla mało wprawnych obserwatorów tamtejszych zabytków było oczywistością, z czego należałoby wnioskować, że prawdziwy cel tego zabiegu był inny. Na podstawie powyższych uwag możemy go sformułować bez trudu: Manteuffel jeszcze raz przeciwstawiał inność Inflant dominującej wówczas na tamtych ziemiach kulturze rosyjskiej. Po raz kolejny dawał odpór rusyfikacji i stopniowego wykorzeniania zachodnich wpływów, działał równocześnie jako obrońca inflanckiej odrębności, polskiego wkładu w kulturę Inflant oraz żyjącego tu od wieków niemiecko-inflanckiego rycerstwa. Łączył odmienności i maskował różnice, by posklejać w całość coś, co mimo wysiłków w całość posklejać się nie chciało.

\footnotetext{
${ }^{16} \mathrm{~W}$ roku 2013 dobiegły końca wieloletnie starania grupy łotewskich historyków o ponowne wydanie Terra Mariana. Księga ukazała się w Rydze pod auspicjami Łotewskiej Biblioteki Narodowej (2013): Terra Mariana 1186-1888. Albums un komentari, red. H. Soms, R. Kaminska i in. Ryga: Latvijas Nacionālā Bibliotēka. Zachowując oryginalny rozmiar księgi, wydawcy podzielili ogromny materiał na dwa tomy, z których pierwszy zawiera szkice historyczne oraz szczegółowe komentarze do poszczególnych kart, natomiast drugi - siedemdziesiąt kolorowych ilustracji, wiernie oddających intrygujące bogactwo oryginału.
} 
Godna podziwu jest wieloletnia praca tego zapamiętałego inflantofila, który czerpiąc z różnych dziedzin, a także rozmaitych języków i kultur, konstruował kolejne narracje o przedmiocie, którego istnienie wciąż budziło wątpliwości i dlatego wymagało nieustannego podtrzymywania w tekstach. Jego wielki projekt inflancki nie zdołał ufundować naukowego bytu krainy, stanowi natomiast przejmujące świadectwo prób i wciąż ponawianych walk historyka o prawo do własnej perspektywy badawczej, do własnej opowieści o rodzinnej ziemi.

Wielokulturowy i interdyscyplinarny projekt inflancki Gustawa Manteuffla nieodwracalnie upadł wraz z nastaniem wieku XX i jego rewolucyjnymi przemianami i tendencjami niepodległościowymi ludów bałtyckich. Budowany na wyobrażeniu o wielokulturowości i wieloetniczności tych ziem, szedł dokładnie pod prąd ówczesnym tendencjom politycznym i społecznym, których osią był etniczny nacjonalizm. Wielokrotnie przez Manteuffla $\mathrm{p}$ i s a n e Inflanty nie zostały właściwie $\mathrm{n}$ a $\mathrm{p}$ i s a $\mathrm{n}$ e $\mathrm{w}$ tym sensie, że z produkowanych przez niego tekstów nikt ich nie wyczytał. Używając innego języka można by stwierdzić, że nie doszło do transakcji przedstawieniowej, ponieważ zabrakło chętnych na ten typ reprezentacji. Manteufflowy „projekt Inflanty” sporządzany był głównie na potrzeby polskiego czytelnika, u którego najwyraźniej nie występował popyt na tak sformatowaną narrację kulturową. Jak się okazało, niezbywalnym składnikiem ich sposobu istnienia było zanikanie i nieistnienie.

Paradoksalnie, zapominane przez cały wiek XX Inflanty przetrwały jedynie w groteskowym zniekształceniu, jakie stało się ich udziałem w Trylogii Henryka Sienkiewicza. Na początku wspominałem już o tym, że Zagłoba dwukrotnie w Potopie przedstawia naszą krainę jako przedmiot politycznej transakcji ze Szwedami, co można uznać za jedyną udaną reprezentację Inflant, chociaż przekształconą w „sprzedawanie Inflant”, czyli reprezentację koślawą i ułomną. W Ogniem i mieczem Longinus Podbipięta dosiada „ogromnej kobyły inflanckiej” (t. I, rozdz. 3), która jest zwierzęciem dosyć pokracznym i dziwnym - jak cała reprezentacja Inflant w polskiej historiografii. Nasze ziemie - tym razem jako Kurlandia - pojawiają się również w Panu Wołodyjowskim (rozdz. XVII), jako miejsce ucieczki Ketlinga, zrywającego bolesny i skomplikowany związek uczuciowy z Krysią. Regiony bałtyckie to dobre miejsce do znikania, zaszycia się w krainie Nigdzie, która jeżeli w ogóle istnieje, to i tak nikt o niej nic nie wie.

Jeszcze inaczej rzecz ujmując, dawne Inflanty Polskie stanowią modelowy wręcz przykład kultury pogranicza, gdzie płynność i nieokreśloność tkwi w samej istocie przedmiotu. Terytorialne uwikłanie, archipelag małych kultur lokalnych, nawarstwiające się wpływy kolonialne i imperialne, zmienność granic, struktury zaludnienia, religii i wyznan - wszystko to generuje tak zwane sytuacje pograniczne, w których niedookreśloność, chwiejność kryteriów i mnogość perspektyw prowadzą do ułomnej ontologii. Baumanowska „płynna nowo- 
czesność" urasta w tych warunkach do naczelnej kategorii definiującej, co odnosi się nie tylko do dawnych Inflant Polskich, ale do całych posarmackich kresów wschodnich Rzeczpospolitej. Miały one swoją specyfikę kulturową i usiłowały ją zgłaszać w swoich wielokulturowych projektach, ale właśnie z powodu tejże specyfiki były wyrzucane na margines istnienia. 